\title{
Data Acquisition and Remote Monitoring System for Indoor Environmental Parameters
}

\author{
MITAR S. SIMIĆ, University of Banja Luka, \\ Faculty of Electrical Engineering, Banja Luka, \\ Bosnia and Herzegovina \\ DANIEL I. PETRISOR, “Gheorghe Asachi” Technical University of Iasi,
}

Faculty of Electrical Engineering, Energetics and Applied Informatics, Iasi, Romania

\begin{abstract}
In this study a wireless sensor network for collecting information about indoor temperature, relative humidity and light level in four positions inside an office building is developed. Infrastructure of wireless sensor network is based on MAC and PHY layer of IEEE 802.15.4 standard and JenNet network protocol stack. The hardware of the system is built integrating JN5148 Evaluation Kit and a Hit65 GSM modem. Features integrated in the architecture of proposed system comprise: SQL database storage of results, real-time graphical trends of measured values, histograms with selection of the start and end date, adjustable sampling time, alarm notification via e-mail and SMS, and GSM and LAN remote access to the sensor readings. These implemented features give our system high practical value with possible application in large-scale environment monitoring of buildings aimed to improve work efficiency and thermal comfort of people and storage or working conditions for materials and equipment.
\end{abstract}

Key words: data acquisition, GSM modem, indoor environmental monitoring, wireless sensor network

\section{INTRODUCTION}

Indoor environmental parameters have huge impact on humans, equipment and materials. Temperature, humidity and lighting are not treated as indoor pollutants, but parallel monitoring of these parameters in real-time is required because it is realized that coexistence of some over-limited parameter can significantly increase impact of other indoor environmental parameters. For example, temperature increases reaction rate of many chemical reactions [1]. Result of the study where effects of different ambient air temperature and relatively humidity on the performances of passive diffusive samplers for measuring nitrogen dioxide $\left(\mathrm{NO}_{2}\right)$ in the outdoor environment are presented in [2]. Also a study presented in [3], showed that combination of low outdoor temperature with high indoor humidity can cause building damage and mold growth.

Indoor temperatures between $20{ }^{\circ} \mathrm{C}$ and $25^{\circ} \mathrm{C}$ in winter and between $23{ }^{\circ} \mathrm{C}$ and $27{ }^{\circ} \mathrm{C}$ in summer are generally perceived by building occupants as comfortable [4]. At these temperatures, relative humidity

Author's address: Mitar Simić, University of Banja Luka, Faculty of Electrical Engineering, Banja Luka, Patre 5, Bosnia and Herzegovina

Paper received: 03.03.2015.

Paper accepted: 19.05.2015. levels between $30 \%$ and $60 \%$ will provide the optimal living conditions for occupants [4]. Conditions outside these ranges, can affect the thermal environment and cause discomfort for building occupants and damage to the building materials and electrical equipment [3].

For correct functioning of electrical equipment, it is necessary to achieve specific conditions regarding indoor temperature and relative humidity. There are some limits for temperature caused by special characteristics of this equipment: it can be switched off because of overheating or frosting. And also there are limits for air humidity in order to save it from corrosion or from electrostatic discharge events. An example of thermal climate in a data center study is presented in [5].

In public buildings and as well as in many office buildings, it is necessary to establish and regulate the thermal comfort for humans, different types of equipment and documentation as well.

Temperature and humidity variations have serious impacts on paper documents because they can cause deformation and accelerate their aging. There are also indirect damages caused by light, acids, harmful gases, worm and bacterium [6].

Good lighting design is marked as an necessary factor for a good indoor environment, because it can 
improve work efficiency and reduce building operating costs. In the same time light is also one of the primary damaging factors and can produce different negative effects for indoor equipment and documentation [7].

Information about environmental parameters is usually collected by sensor networks. Sensors can be connected in different network topologies, depending on application and resources, but the main division for sensor networks rely on the type of communication link: wireless and or cable networks. Wireless sensor networks (WSN) transfer sensor readings through the wireless network infrastructure without setting up electric wiring. Compared to the cable network, WSN has the advantage that does not depend on any preexisting infrastructures. Taking these aspects in consideration a WSN can be easily deployed in structures where no prior plans were available or construction changes are not acceptable [8]. Successful integration examples of WSN indoor monitoring systems include museums [1], libraries [6], old buildings [7], transportation systems [9], etc. WSN are widely used in outdoor environment monitoring as well. The advantage of wireless communication links over cable networks in case of very long distances is obvious and also offers the possibility that network infrastructure can be easily changed or removed. This can be very useful in case of experiments conducted in the field, especially continuous collection of monitoring data in specific seasons of year.

Based on these facts it is obviously that development of reliable and stable environmental monitoring and data acquisition systems is very important, and has a wide range of applications in industrial and nonindustrial domains. Main characteristics of systems reported earlier [10]-[13] include: wired communication links, local data visualization, local data storage on a micro SD card, LED alarm notification and PC support with LabVIEW and Windows applications.

In this study a wireless sensor network for data collection and monitoring of indoor parameters as temperature, relative humidity and light level is developed. The hardware infrastructure of our proposed system is based on JN5148 wireless development kit that can be used either in indoor or outdoor environments. In the case of proposed system, the wireless infrastructure was used for data acquisition of indoor environment parameters in an office building of "Gheorghe Asachi" Technical University of Iasi.

Due to the fact that JN5148 is available as a commercial development kit, the main contribution of our proposed system is constituted by the realization of a complex server unit connected with WSN coordinator through serial communication interface. The development of the server software architecture has integrated features like: graphical presentation of measured values (real-time trends), interactive histograms with adjustable selection of start and end date, adjustable sampling time, alarm notification via e-mail and SMS and remote access to the stored sensor readings. These features give our system high practical value with possible application in large-scale building monitoring solutions intended to improve work efficiency and thermal comfort of people and also storage or working conditions for materials and equipment.

\section{SYSTEM ARCHITECTURE}

In this study, a WSN based on IEEE 802.15.4 standard and JenNet network stack, is used to collect information about temperature, relative humidity and light level inside an office building. Block-scheme of developed system is presented in the Figure 1.

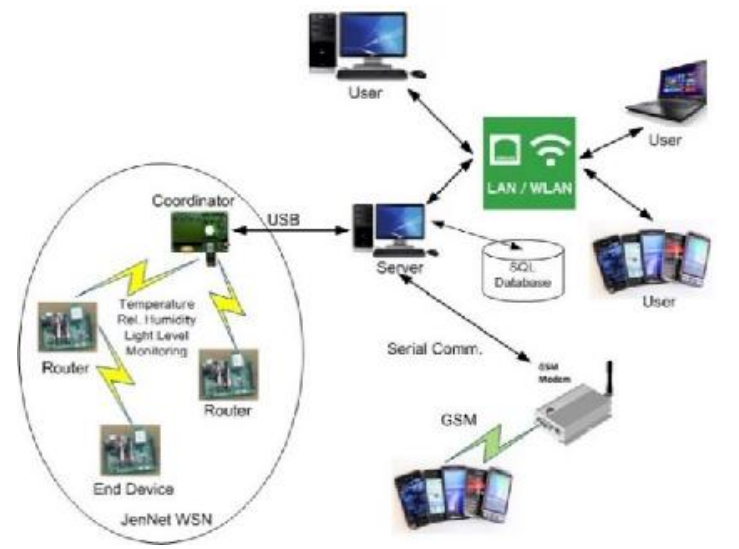

Figure 1 - Wireless network infrastructure used for indoor environmental monitoring in an office building

Deployed JenNet WSN consists of the Coordinator, two Routers and one End Device. Readings from nodes are wirelessly transmitted to the Coordinator for local presentation on the display. The coordinator transmits sensor readings to the PC (Server unit) at regular time intervals of approximately one time per second. The system server runs a special developed Windows application that stores sensor reading received from the network in a SQL database and accurately presents the detailed measurements..

Besides a direct reading from Windows application, there are two more modes of remote access to the sensor readings by SMS or web server as shown in Figure 1. The first method that facilitates data visualization is by SMS query from a mobile phone. The GSM modem connected in the systems architecture forwards the received text message to the Server unit which parses received string and if query is valid data readings from specific sensors are send back to the requester via a SMS. The command string must contain a valid keyword and password and a correct data 
query request for specific sensor readings. Data requests could target a specific node or can address all the nodes of the indoor monitoring network. Data request options are specifies accordingly into the command string send to the modem by means of a text message. The GSM modem is also used to send alarm notifications to the authorized personnel responsible of managing special risk situations that may occur. A second option that allows remote access to sensor readings is by using network devices attached to the same local network as the server computer. Computers and smart phones devices connected to the local area network could be able to access the data visualization interface developed as a .NET application and deployed on the IIS (Internet Information Service) of the system server.

\subsection{The IEEE 802.15.4 Standard}

IEEE 802.15 .4 standard was defined in 2003 by the IEEE 802.15 working group. It is a standard which specifies the physical layer (PHY) and media access control (MAC) for low-rate wireless personal area networks (LR-WPANs) [14].

Architecture of the low-rate wireless personal area networks is based on number of layers, each responsible for one part of the standard. In the same time, low-level layers provide required services to the higher layers [15].

The physical layer (PHY) contains the radio frequency transceiver with its low-level control mechanism. A media access control (MAC) sub layer provides access to the physical channel for all types of transfer [14].

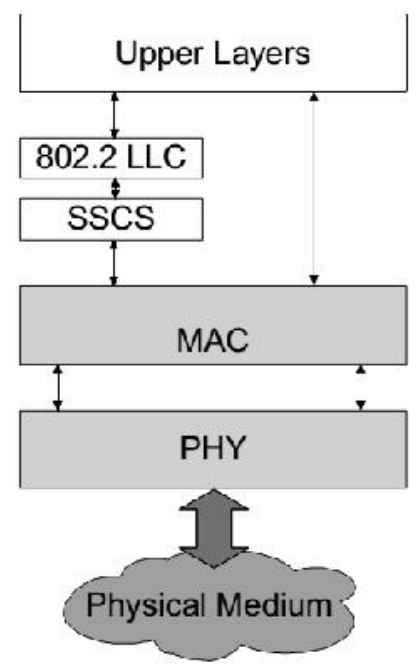

Figure 2 - LR-WPAN device architecture [14]

The upper layers, shown in Figure 2, consist of a network layer and an application layer [14].

The definition of these upper layers is outside the scope of IEEE 802.15.4 standard but specifications, such as 6LoWPAN, ZigBee and JenNet are build on this standard. The JenNet network stack is used in proposed system and it is described in the following section of the paper.

\subsection{JenNet network stack}

JenNet is a wireless networking stack based on the IEEE 802.15.4 standard developed by Jennic in 2007 [16]. It was special designed to offers the capability of being fully scalable from just a few nodes to large networks of up to 1000 nodes [17].

With implemented JenNet stack a wide range of network topologies are possible (star, tree or linear formations) for long strings of nodes. Main features such as: self-configuration, automatic healing, low power and sleep mode configured end devices, encryption of data packets and over the air download for easy software update of nodes ensure that JenNetbased networks are tolerant to node failures with secure data transmission and multi-year battery life [17]. It also offers good co-existence with $\mathrm{WiFi}$ and Bluetooth networks because it is based on the IEEE802.15.4 standard at 2.4GHz.

JenNet network layer manages: network formation, network discovery, network joining and repair, and the mechanism of communication data packets between neighboring nodes [17]. Jennic offers hardware chips and modules with 32-bit microcontrollers that allows them to run any of the current standards based stacks (IEEE 802.15.4, JenNet, ZigBee PRO). Example of such kit is JN5148-EK010 Evaluation Kit which is described in the following section of the paper.

\subsection{JN5148-EK010 Evaluation Kit}

The JN5148-EK010 Evaluation Kit, developed by Jennic, consists of the following components (Figure 3 ): one Controller board (labeled on the picture with 1), four sensor boards (2), two high-power plug-in modules with uFl connector (3), three SMA-connector antennae (4), two USB-to-Serial (FTDI) cables (5), one pack of 10 AAA batteries for the boards (6).

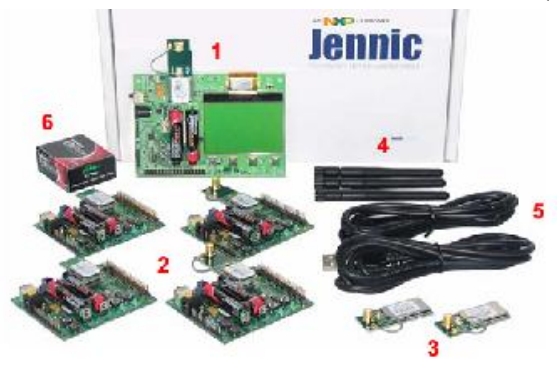

Figure 3 - JN5148-EK010 Evaluation Kit Components [17]

The Controller board is a DR 1047 [17]. It contains LCD screen, four configurable LED indicators, four configurable push-button switches, temperature sensor, humidity sensor, light sensor, serial EEPROM, 
UART interface for communication and program downloads and expansion port for additional sensors.

The four Sensor boards are physically identical and each board is a DR1048 board [17]. It contains 2 configurable LED indicators, 2 configurable push-button switches, temperature sensor, humidity sensor, light sensor, serial EEPROM, UART interface for communication and program downloads and expansion port for additional sensors.

\section{SERVER UNIT}

The server unit is running Windows and Web applications as it is shown in the Figure 4 and Figure 5. Windows application collects and processes all sensor data for graphical presentation and storing in a SQL database. Remote data visualization is accomplished by means of a Web (.NET) application, which has access to the same database in read-only mode, and presents data measured and stored in an interactive interface that allows users to easy navigate recent data by moving forward and backward through sensor readings. The interactive data visualization application is deployed in the IIS (Internet Information Service) of the server so other computers in the network have access to this interface.

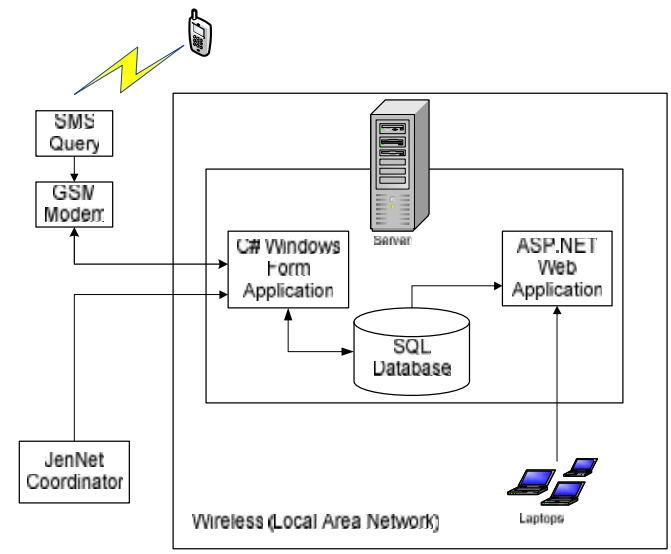

Figure 4 - Data flow of measured values from sensor nodes to the remote user

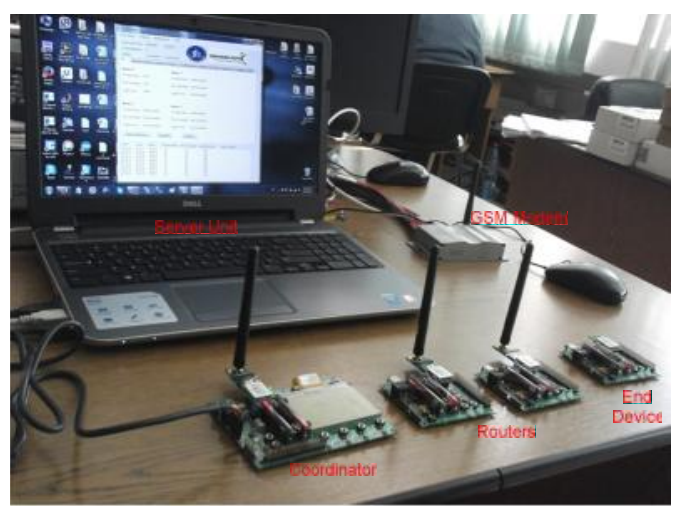

Figure 5 - Server running Windows application with connected JenNet coordinator and GSM modem
In the following text, main features of developed Windows and Web applications are presented.

\subsection{Windows application for data visualization}

In the Figure 6, main window of application for environmental monitoring inside an office building is presented. As may be seen, data presentation is organized in tabs which allow easy manipulation between nodes and specific sensor groups. Above tabs basic information are presented: date, time, connection status and defined sampling time. Connection with JenNet coordinator can be done by clicking on item "Connect JenNet Coordinator" in "Connection" menu group, a new window will open and user has to choose COM port of server computer connected with JenNet coordinator. If a connection attempt was successful, a confirmation message will be displayed and the system will start to retrieve data from JenNet coordinator. Tab "All" will present sensor readings of all nodes which are joined to the monitoring network, while faulty or disconnected nodes are marked as "Not Available".

By clicking on a tab to select a specific node for data visualization, sensor readings from that node are presented. Minimum and maximum values for temperature, relative humidity and light level are presented as well. There is also an option available in the user interface meant to add a short description to characterize any specific node. This text can be easily changed and updated.

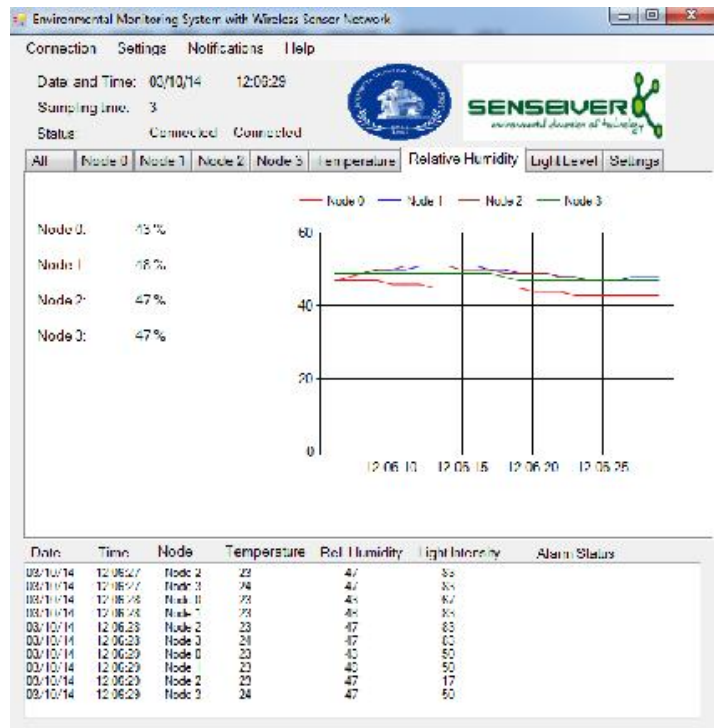

Figure 6 - Main window of application for environmental monitoring inside the office building with selected relative humidity tab

By clicking on tab for specific sensor group (temperature, relative humidity or light level), readings from all nodes are presented. Available in the data visualization interface there is also graphical presentation of measured values with time and date stamp on $\mathrm{x}$-axis that facilitates data analysis of a time interval. 
Sampling time and alarm values can be changed by clicking on items "Sampling Time" and "Alarms" in "Settings" menu group, respectively. Sampling time defines the delay between storing two entries in database having a default value of one second. Reception of values from JenNet coordinator is not affected by changes to this value. By default alarms are disabled, but they can be easily enabled with custom alarm values. There is also an option for restoring to the default values. Sampling time and alarm values are stored in database so they will be used for the next start of the system.

There is also an option for alarm notification by email or by phone. List of persons who should be notified in case of emergency can be updated by clicking on item "Settings" in "Notifications" menu group. A new window will then opened, and existing users can be viewed, changed or deleted and new users can be added as well. For each user, alarm notification can be enabled or disabled at any time.

As noted before, remote access to sensor readings is enabled to users from the same LAN. These users can only read measured values while the administrator has the option to delete from Server application all or any specific entry from the database. Database management is called by clicking on button "Database" in "All" tab.

By using the tab "All", users also can select an option for plotting graphs or alarm listing by clicking one of the buttons "Graphs" and "Alarms", respectively. In both cases, a new window will open as shown in Figure 7. Users can choose node and sensor to filter values in specific date ranges. Generated graph or alarm list can be exported as bitmap or text file, respectively.

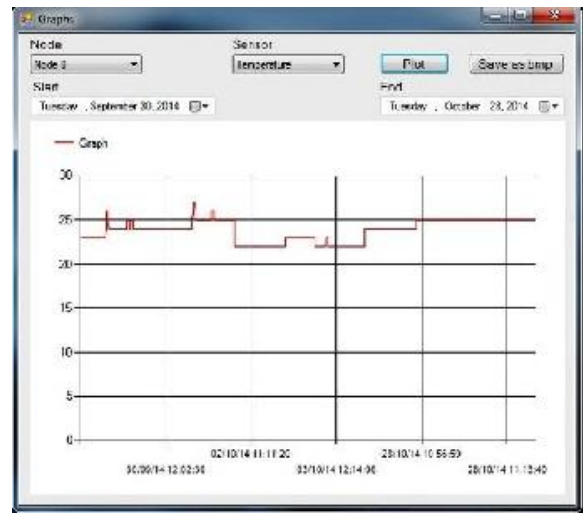

Figure 7 - Database management interface for graph plotting

\subsection{Remote access to the server web page from network computers}

Access from other devices in the network can be established through Internet browser by typing "IP_address_of_the_server: port_number/tui.aspx" in adress field. Access was tested in two Wireless Local Area Networks: at the TUI and at the IL PRIMO hotel with two different types of devices as it is shown in Figure 8.

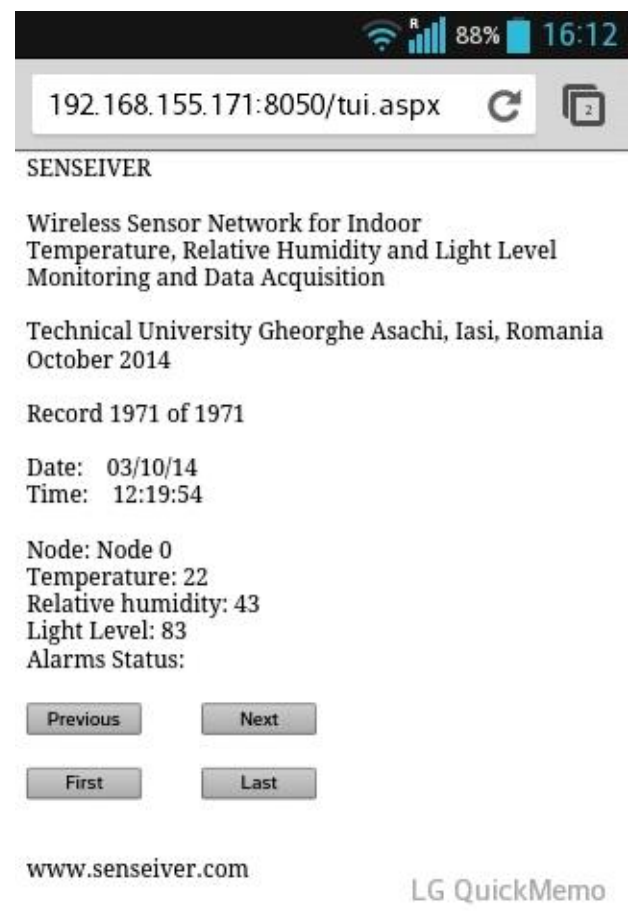

Figure 8 - Access to the server web page from TUI's WLAN

\subsection{Remote access from mobile phone by SMS query}

As noted before remote access to the sensor readings is possible with SMS query from mobile phone. This can be easily done by sending an SMS to the number of SIM card inserted in GSM modem. The GSM modem integrated into our system is an Industrial Terminal Hit65T [18].

A connection with the GSM modem can be done by clicking on item "Connect GSM Modem" in "Connection" menu group, after this a new window will be open and users have to choose a COM port of the computer which will be used to connect with GSM modem. If a connection attempt was successful, confirmation message will be displayed and system will change the label in the main window from "Disconnected" to the "Connected" indicating that modem is connected.

Format of the text message that should be sent to number of the SIM card is "Keyword PIN_code Node Number_of_node(s)". For example, if a received message contains the following string "SENSEIVER 8586 Node0123", the GSM modem will respond with sensor readings from all nodes. In case one specific node of the monitoring network is disconnected, the response message to a data request from this node will contain the string "NA", indicating that node is not 
available. The implemented data query command structure makes it possible to request data from one node only or from multiple specific node(s). For example, a data query from node 0 could have the following SMS command string "SENSEIVER 8586 Node0", or if the data request targets booth node one and node three a SMS command could be "SENSEIVER 8586 Node13".

\section{SUMMARY}

In this study a system for wireless collection of information about indoor temperature, relative humidity and light level in four locations inside an office building of The "Gheorghe Asachi" Technical University of Iasi was developed.

The system was tested during one and a half month and showed stable and reliable operation during this work period. Future plans for this system consists in software and hardware expansion, by means of new sensors integrated into the system and new application features to enhance data analysis and interpretation. Integration of new sensors suitable for indoor environment monitoring into the architecture of our system is targeted to sensors for carbon oxide and carbon dioxide measurements. A new deployment of developed .NET application based on web-hosting service and integrating the usage of GPS transceivers will increase practical value of our system by allowing remote system access via Internet and retrieving of node geo location information.

\section{ACKNOWLEDGEMENT}

This work was financially supported by European Commission in the framework of the FP7 project SENSEIVER, grant number 289481. The authors gratefully acknowledged the NORTH Point Ltd. Subotica, Serbia and "Gheorghe Asachi" Technical University of Iasi, Iasi, Romania for supporting the research work.

\section{REFERENCES}

[1] M. Bacci, C. Cucci, A. A. Mencaglia, and A. G. Mignani, "Innovative Sensors for Environmental Monitoring in Museums", Sensors, 2008, Vol. 8(3), 1984-2005.

[2] V. Šerevičienè, D. Paliulis, "Influence of Temperature and Relative Humidity on the Performance of Nitrogen Dioxide Diffusive Sampler", Research Journal of Chemical Sciences, Vol. 2(5), 89-92, May 2012.

[3] A. Rudd, H. I. Henderson, "Monitored Indoor Moisture and Temperature Conditions in Humid Climate US Residences", American Society of Heating, Refrigerating and Air-Conditioning Engineers, Volume 113, Part 1.
[4] ISO 7730, 1984.

[5] P. Krapivnitckaia, "Thermal Climate In A Data Center", Mikkeli University of Applied Sciences, BSc Thesis, 2013.

[6] N. Li, Y. Tang, "Library Temperature and Humidity Remote Control System Based on Micro Controller Unit", Proceedings of the 2nd International Conference on Computer Science and Electronics Engineering ICCSEE 2013.

[7] M. Zarzo, A. F. Navajas and F. J. G. Diego, "LongTerm Monitoring of Fresco Paintings in the Cathedral of Valencia (Spain) Through Humidity and Temperature Sensors in Various Locations for Preventive Conservation", Sensors, 11, 8685-8710, 2011.

[8] H. T. Anastassiu, S. Vougioukas, T. Fronimos, C. Regen, L. Petrou, M. Zude and J. Käthner, "A Computational Model for Path Loss in Wireless Sensor Networks in Orchard Environments", Sensors, 14, 5118-5135, 2014.

[9] D. Tacconi, D. Miorandi, I. Carreras, F. Chiti, R. Fantacci, "Using wireless sensor networks to support intelligent transportation systems", Ad Hoc Networks, 8, 462-473, 2010.

[10]M. Simic, "Microcontroller Based System for Measuring and Data Acquisition of Air Relative Humidity and Temperature", In the Proceedings of the $37^{\text {th }}$ International Conference of IMAPS-CPMT Krakow, Poland, 22-25 ${ }^{\text {th }}$ September, 2013.

[11]M. Simic, M. Siretenau, "Real Time Temperature And Relative Humidity Monitoring System Using LabView", In the Proceedings of the ETIKUM 2014, Novi Sad, Republic of Serbia, June 19-20 2014.

[12]M. Simic, "Design and Development of Air Temperature and Relative Humidity Monitoring System With AVR Processor Based Web Server", In the Proceedings of the EPE 2014, Iasi, Romania, October $16-18^{\text {th }} 2014$.

[13]M. Simic, "Design of Monitoring and Data Acquisition System for Environmental Sensors", In the Proceedings of the INDEL 2014, Banja Luka, Republic of Srpska, Bosnia and Herzegovina, November 6-8th, 2014.

[14]LAN-MAN Standards Committee of the IEEE Computer Society, "Wireless Medium Access Control (MAC) and Physical Layer (PHY) Specifications for Low-Rate Wireless Personal Area Networks (LRWPANs)", IEEE, 2003.

[15]L. M. Lellan, D, Whittaker, S. Workman, "The OSI Reference model", CISCO Systems. 
[16][http://www.epn-online.com/page/new52676/jenniclaunches-jennet-stack-for-scalable-wireless-sensornetworks.html\#, (last accessed on 24th October 2014).
[17]NXP JenNet Stack, User Guide, Revision 2.0, 2010.

[18]Terminal Hit65T, datasheet

\section{REZIME}

\section{BEŽIČNA SENZORSKA MREŽA ZA DALJINSKI NADZOR I AKVIZICIJU PARAMETARA RADNE SREDINE U POSLOVNIM OBJEKTIMA}

U ovom radu je opisana bežična senzorska mreža za prikupljanje informacija o temperaturi, relativnoj vlažnosti i nivou osvjetljenja u poslovnim objektima. Mrežna infrastruktura je zasnovana na MAC i PHY nivou IEEE 802.15.4 standarda i JenNet mrežnom protokol steku. Hardver predloženog sistema je baziran na JN5148 razvojnom sistemu i Hit65 GSM modemu. Sistem objedinjuje SQL bazu podataka za čuvanje rezultata, grafičku prezentaciju izmjerenih vrijednosti u realnom vremenu, mogućnost podešavanja pauze između dva mjerenja, pregled rezultata mjerenja na svim mjernim mjestima (histogrami) kao i obaviještavanje o alarmima putem SMS-a i e-maila. Takođe, daljinski pristup rezultatima mjerenja putem LAN-a je omogućen. Implemtirane karakteristike daju razvijenom sistemu veliku praktičnu vrijednost sa mogućnošću primjene u monitoring sistemima većih razmjera sa ciljem da se kreiraju optimalni radni uslovi i poveca radna efikasnost zaposlenih.

Ključne reči: akvizicija podataka, bežične senzorske mreže, GSM modem 